Reprinted with permission from: Weed Technology. 1996. 10:601-609.

Published and copyrighted by: Weed Science Society of America, http://www.wssa.net

\title{
Rhizobacteria as biocontrol agents of weeds ${ }^{1}$
}

\author{
ROBERT J. KREMER and ANN C. KENNEDY ${ }^{2}$
}

\begin{abstract}
:
There is a current need to develop alternative weed management techniques in response to demands for reduction in herbicide use due mainly to health and environmental concerns. Therefore, all possible nonchemical strategies for weed control should be considered, including biological control. Deleterious rhizobacteria (DRB), largely overlooked as potential biological control agents for weeds until recently, are able to colonize root surfaces of weed seedlings and suppress plant growth. Limited field studies indicate that DRB suppressed weed growth, and reduced weed density, biomass, and seed production. In this manner, crops out-compete the suppressed weeds for growth requirements, eliminating the necessity for eradication of weeds in the crop. Establishment of DRB as a viable biological control strategy initially will require integration with other weed control approaches including other biocontrol agents, agrichemicals, and cultural and residue management practices. To achieve success, more indepth research is needed on ecology of bacteria-plant relationships, mechanisms of action (including characterization of phytotoxins), inocula formulations, and methods to enhance crop competition.
\end{abstract}

\section{Additional index words:}

Biological control, competition, efficacy, growth suppression, integrated weed management, microbial ecology, phytotoxins, weed seedlings, Pseudomonas spp.

\footnotetext{
${ }^{1}$ Received for publication Sept. 20, 1994 and in revised form Feb. 10, 1996. Contribution from Agric. Res. Serv., U.S. Dep. Agric., Crop. Syst. Water Qual. Res. and Missouri Agric. Exp. Stn. J. Ser. No. 12154, and Agric. Res. Serv., U.S. Dep. Agric. and Coll. Agric. and Home Econ. Res. Cent., Washington State Univ.

${ }^{2}$ Microbiol., U.S. Dep. Agric., Agric. Res. Serv., 144 Mumford Hall, Columbia, MO 65211. Soil Sci., U.S. Dep. Agric., Agric Res. Serv., 215 Johnson Hall, Washington State Univ., Pullman, WA 99164-6421.
} 


\section{Introduction}

Weeds cause more economic losses on agricultural lands than all other pests combined. Currently, the most effective means of managing weeds are herbicides, which account for more than $60 \%$ of all pesticides used in crop production (18). Some widely used herbicides have been implicated in contamination of groundwater, soils, and food products, which may threaten public health and safety. The public concern about environmental safety of herbicides has increased interest in developing effective nonchemical weed management methods. Nonchemical alternatives for weed management include manipulation of mechanical control and other cultural practices, crop rotations, exploitation of allelopathic mechanisms, and the development of effective biological control strategies. The role of biological control in an overall management scheme initially may be supplemental to other current approaches; however, this method has promise in becoming a major tool for effective management of weeds in integrated systems (1).

Insects and fungi have traditionally been used in biological control of noxious weeds. Development of effective mycoherbicides, initiated in the late 1970s, has been successful for specific weeds in limited areas (52). Improving the biocontrol efficacy of agents currently in use and screening new agents for use on other important weed candidates are goals of current mycoherbicide research (52). One group of microorganisms largely overlooked as biological control agents of weeds include the deleterious rhizobacteria $(\mathrm{DRB})^{3}$, characterized as nonparasitic bacteria (exopathogens) colonizing plant root surfaces and able to suppress plant growth (51). Initial descriptions of DRB were made on crop plants and they were implicated in suppression of plant growth and development of crops such as sugarbeet (Beta vulgaris L.) (51), potato (Solanum tuberosum L.) (3), and winter wheat (Triticum aestivum L.) (16). Despite the nonparasitic, subtle nature of attack, DRB may be as significant as traditional bacterial pathogens in affecting plant growth $(43,51)$. Many DRB are plant specific $(11,16,40)$; thus, their existence on weeds and their potential as biological control agents has only recently been investigated. DRB with potential as biological control agents were first described on downy brome (Bromus tectorum L. $\#^{4}$ BROTE) occurring in winter wheat fields (11) and on several broadleaf weed seedlings (34). The objectives of this review are to provide a perspective on the development and use of rhizobacteria in biological control of weeds and to examine the possibility for integration of bacterially based biological control into weed management systems.

\section{The rhizobacterial approach to biological weed control}

Practical use of DRB for weed management involves an inundative strategy for applying inocula to establish high numbers of bacteria in the spermosphere and/or rhizosphere and achieve rapid initiation of growth-inhibitory activity. This strategy is

\footnotetext{
${ }^{3}$ Abbreviations: DRB, deleterious rhizobacteria.

${ }^{4}$ Letters following this symbol are a WSSA-approved computer code from Composite List of Weeds, revised 1989. Available from WSSA, 1508 West University Ave., Champaign IL 61821-3313.
} 
similar to the mycoherbicide approach to weed control (10) in that potential agents selected for activity against target weeds are mass-cultured in artificial media from which inocula are developed for field application to control weeds during the growing season before economic crop losses occur. In field studies conducted to date, DRB have typically been applied directly to soil or vegetative residues to attack germinating seeds and emerging seedlings and for eventual suppression of weed growth. This contrasts with the use of most myco herbicides, which are applied to foliage of established weeds at a stage vulnerable for infection by the fungal pathogens. Also, weed management with DRB is not dependent on development of an endemic disease on established weeds, which is the basis for activity of typical plant pathogens comprising most mycoherbicides (10). Rather, the rhizobacteria strategy seeks to regulate development of weeds before or coincident with emergence of crop plants. Therefore, DRB do not necessarily eradicate the problem weed but significantly suppress early growth of the weed and allow the developing crop plants to effectively compete for growth requirements with the weakened weed seedlings. DRB are most effective when weed growth coincides with environmental factors conducive to bacterial growth and plant-suppressive activity (27). The mode of action of DRB is primarily through production of phytotoxins which are absorbed by the seedling roots (53). In this respect, application of DRB to soil for controlling weeds through toxigenicity is similar to the use of necrogenic fungi applied to soil and aquatic habitats where phytotoxins are subsequently produced during fungal proliferation in the weed root zone (10).

Two major considerations affecting implementation of the rhizobacteria approach to biological control of weeds are host specificity and efficacy. Current projects investigating rhizobacteria for biological control include screening procedures designed to assure high specificity toward their weed host(s) with no detrimental effects on growth of nonweedy plant species (26). Screening rhizobacteria simultaneously on weed targets and on crop species in in vitro seedling bioassays has successfully identified agents inhibitory to weed but not crop seedling growth $(21,29)$.

Efficacy of DRB agents can be defined as the ability to provide a satisfactory level of weed control, at an acceptable rate, and ease of fitting into standard pest control practices (9). Thus, efficacy is a function of several characteristics of DRB including root- or seedcolonizing ability, extent and rate of weed suppression, and adaptability to pesticide application methods. Traditional use of herbicides has emphasized elimination of competition from weeds growing in a crop by eradication of the weeds. In this context, DRB as biological control agents are considerably less efficacious than herbicides since DRB are effective primarily through growth suppression. Field tests conducted thus far have revealed that crop yields in plots where, weed growth was suppressed by DRB were significantly higher than for crop yields in plots with healthy weeds (29). Thus, the economic benefits of weed control by DRB do not rely on complete kill of weeds but on reducing the competitive ability of weeds growing with the crop. Kennedy et al. (29) observed weed control efficacy of DRB agents not only as reduction in competitive ability but also as inhibition of biomass accumulation, reduced density, and reduced seed production by downy brome. These and other characteristics influencing biological control activity might be used to develop an assessment protocol and a scheme for rating efficacy of DRB agents similar to that for mycoherbicides (9) as an aid in selecting highly effective agents for commercial development.

Page 3 of 14 


\section{Accomplishments}

Biological control of downy brome in winter wheat by Pseudomonas spp. isolated from downy brome roots has been demonstrated under field conditions (29). Bacteria at $10^{8}$ cells $/ \mathrm{m}^{2}$ were applied to the soil surface in $1 \mathrm{~L}$ water $/ \mathrm{m}^{2}$ of plots infested with downy brome immediately after planting to winter wheat at three field sites in Washington. Two isolates consistently reduced downy brome density, growth, and seed production at all three locations. Representative data from the Washtucna site (Table 1) showed that winter wheat densities were not affected by the bacteria and grain yield was significantly increased. The increase in wheat yields primarily was due to the growth suppressive effects of the applied bacteria on downy brome, which allowed the wheat to be more competitive. The significant reductions in seed production by the surviving downy brome plants in the rhizobacteria-inoculated plots suggested that replenishment of the seed bank was affected and could reduce future downy brome infestations. The processes to obtain bacteria suppressive to downy brome and jointed goatgrass (Aegilops cylindrica Host \# AEGCY) have been patented $(15,30)$ and are under consideration for commercial development. Since downy brome and jointed goatgrass are difficult to control with available herbicides, adoption of a biological control method based on DRB into a weed management strategy for winter wheat appears very promising.

Table 1. Effect of selected rhizobacteria on downy brome growth and winter wheat density and yield at Washtucna, Washington, 1988. Modified from Kennedy et al. 29. ${ }^{\text {a }}$

\begin{tabular}{lcccccc}
\hline & \multicolumn{3}{c}{ Downy brome } & & \multicolumn{2}{c}{ Winter wheat } \\
\cline { 2 - 4 } \cline { 6 - 7 } Treatment & Density & Shoot mass & Total seeds & & Density & Yield \\
\hline & Plants $/ \mathrm{m}^{2}$ & $\mathrm{~g} / \mathrm{m}^{2}$ & no. $/ \mathrm{m}^{2}$ & & plants $/ \mathrm{m}^{2}$ & $\mathrm{~kg} / \mathrm{ha}$ \\
Pseudomonas D7 & $164 \mathrm{a}$ & $18 \mathrm{a}$ & $9000 \mathrm{a}$ & & $31 \mathrm{a}$ & $4360 \mathrm{a}$ \\
Pseudomonas 2V 19 & $188 \mathrm{a}$ & $19 \mathrm{a}$ & $17000 \mathrm{a}$ & & $32 \mathrm{a}$ & $4100 \mathrm{a}$ \\
Non-inoculated & $252 \mathrm{~b}$ & $33 \mathrm{~b}$ & $25000 \mathrm{~b}$ & & $30 \mathrm{a}$ & $3230 \mathrm{~b}$ \\
\hline
\end{tabular}

${ }^{\mathrm{a}}$ Means in columns followed by the same letter are not significantly different $(\mathrm{P} \leq 0.05)$ based on Dunnet's LSD.

Similar work with selected rhizobacteria for growth suppression of downy brome and Japanese brome (Bromus japonicus Thunb. ex Murr. \# BROJA) has been conducted in Kansas $(20,21,23,24)$. In plots seeded alone with downy brome or Japanese brome, early seedling growth was significantly inhibited suggesting that competition from wheat, when present, could reduce weed growth even further (24). However, in studies with winter wheat infested with downy brome, DRB did not significantly inhibit weed growth, although increased grain yields were detected with several isolates $(21,24)$. Field studies were established under adverse environmental conditions (high temperatures, low soil moisture), which probably reduced survival and root colonization of DRB, essential requirements for successful inhibitory activity. These results emphasize the need to develop inocula formulations that maintain or enhance efficacy of rhizobacteria when applied under harsh conditions typically encountered in the field.

Begonia (4) used rhizobacteria isolated from velvetleaf (Abutilon theophrasti Medicus \# ABUTH) rhizospheres formulated in granulated peat to reduce velvetleaf 
emergence in greenhouse and field studies. The pseudomonad isolates, Pp001 and Pf239, significantly $(\mathrm{P} \leq 0.05)$ reduced velvetleaf seedling emergence $(<55 \%)$, decreased seedling vigor, and increased the nonviable portion of seeds in soil compared to the noninoculated control (Figure 1). Thus, inocula applied to soil prior to seedling emergence were effective in attacking germinating seeds and emerging seedlings. Consequently, a simultaneously emerging crop could benefit from reduced competition from weakened velvetleaf and depletion of the seed bank could potentially reduce future infestations (33).

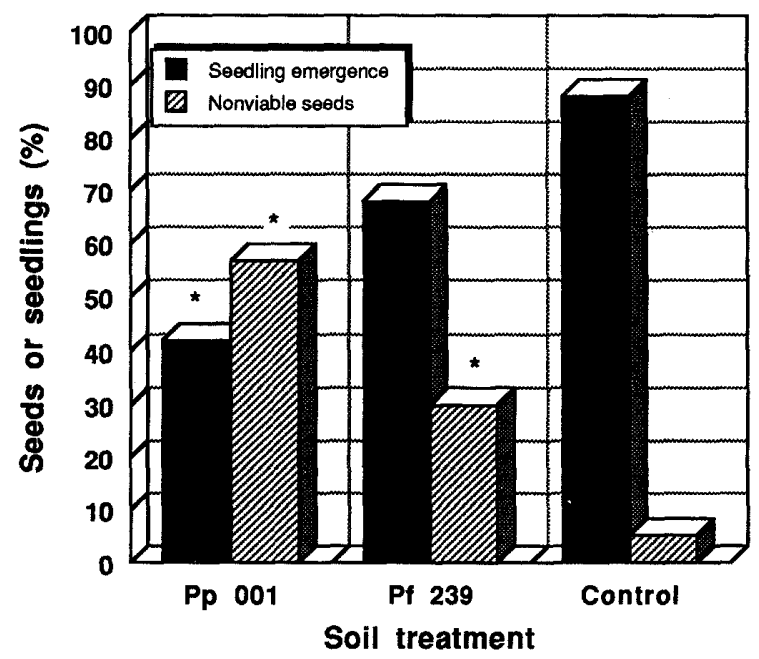

Figure 1. Effect of soil inoculation with two rhizobacteria isolates on seedling emergence and seed viability of velvetleaf. Treatments: Pp001, Pseudomonas putida strain 001; Pf239, Pseudomonas fluorescens strain 239. *Indicates significant difference $(\mathrm{P} \leq 0.05)$ from control based on LSD. Data from Begonia (4).

\section{Current status}

At least 11 projects in the United States and Canada are actively involved in developing DRB for biological control of weeds (Table 2). There were 18 weed species identified as targets for control by DRB. The majority of projects (8 of 11) focused on controlling economically important annual weeds in cereal and row crops. The remaining projects deal with biological control of perennial weeds of rangeland and forest ecosystems. All projects involve screening isolates in preliminary laboratory tests either as the initial stage of a new project or as a continuing effort of established projects. Nearly all projects have identified Pseudomonas spp. as the major group with potential as effective candidates for biological control. Representative isolates from five other gram-negative genera were also under study. These bacterial groups are typical rhizosphere bacteria with high root-colonizing abilities (32). By far, the greatest effort in development of rhizobacteria for practical use has been with grassy weeds in winter wheat where three or more years of large-scale field trials have been conducted. Interestingly, five projects underway in Missouri, Montana, British Columbia, Ontario, and Saskatchewan are associated with simultaneous, on-going investigations of fungi as potential biocontrol agents, most of them targeted for the same weeds as the DRB candidates. This indicates the use of DRB is recognized as a potentially viable biological control strategy equivalent to the mycoherbicide approach. 


\section{Strategies for integration of rhizobacteria into weed management}

Development and acceptance of effective biological control systems based on DRB will be challenged by factors limiting their spectrum of activity, efficacy, and reliability. DRB, despite selection for suppression of specific weed species, can potentially inhibit a wide range of plant species. For example, a group of DRB inhibitory toward downy brome but not winter wheat also inhibited growth of two broadleaf weeds in in vitro bioassays (Figure 2). Ability of DRB to inhibit a wide range of weed species would be desirable; however, the increased potential for crop inhibition must be recognized. Only DRB with narrow host ranges have been used in the field to avoid possible detrimental effects on crops. The limited spectrum of activity and susceptibility to adverse effects of certain environmental factors contribute to the perception of DRB as less efficacious than herbicides. Thus, integration of DRB, with other nonchemical and chemical controls should be considered to attain high levels of growth suppression of multiple weed species in a broad range of cropping systems.

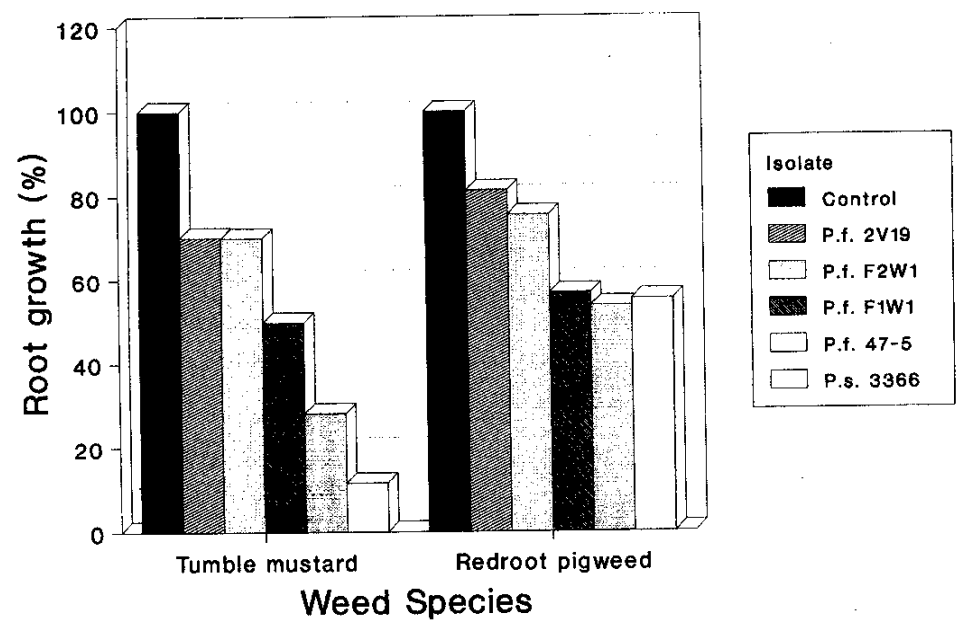

Figure 2. Inhibition of root growth of tumble mustard, and redroot pigweed seedlings by rhizobacterial cultures in agar plate bioassays. A. C. Kennedy, unpublished data.

Integration with agrichemicals is an approach that has been used successfully to improve activity of mycoherbicides toward certain weeds $(25,46)$ and recently has been applied to the use of DRB. Greaves and Sargent (19) found that colonization of wheat roots by Pseudomonas spp. was greatly enhanced and resulted in extensive cellular and tissue damage when plants were treated with mecoprop [( \pm )-2-(4-chloro-2-methylphenoxy) propanoic acid]. They suggested that exploitation of plant-herbicide-microorganism interactions potentially could be an effective strategy for biological control of weeds. Rhizobacteria inhibitory to downy brome and jointed goatgrass exhibited higher growthsuppressive activity in soil when combined with herbicides at reduced rates of application $(22,50)$. Growth suppression by some DRB combined with metribuzin [4-amino-6-(1, 1 -dimethylethyl)-3-(methylthio)-1,2,4-triazin-5(4H)-one] and diclofop [( \pm -2-2-[4-(2,4dichlorophenoxy) phenoxy]propanoic acid] applied at sub-lethal rates was additive. Diclofop plus bacteria increased root growth suppression of downy brome by 0 to $12 \%$ over diclofop alone (50). Further research into the mechanisms of herbicide-rhizobacteria 
Table 2. Biological control of weeds projects based on rhizobacteria.

\begin{tabular}{|c|c|c|c|c|c|}
\hline $\begin{array}{l}\text { Investigator(s) } \\
\text { /Location }\end{array}$ & Weeds $^{\mathrm{a}}$ & Ecosystem $^{\mathrm{b}}$ & Rhizobacteria & Status $^{c}$ & References \\
\hline $\begin{array}{l}\text { A. Caesar } \\
\text { USDA-ARS } \\
\text { Bozeman, MT }\end{array}$ & $\begin{array}{l}\text { EPHES } \\
\text { CENRE }\end{array}$ & Rangelands & $\begin{array}{l}\text { Agrobacterium } \\
\text { Pseudomonas } \\
\text { Xanthomonas }\end{array}$ & $A, \mathrm{~B}, \mathrm{C}$ & $\begin{array}{l}7,8 ; \\
\text { Pers. comm. }\end{array}$ \\
\hline $\begin{array}{l}\text { J. Clapperton, } \\
\text { R. Blackshaw } \\
\text { Agric. Canada } \\
\text { Lethbridge, Alberta }\end{array}$ & $\begin{array}{l}\text { SETVII } \\
\text { AVEFA }\end{array}$ & $\begin{array}{l}\text { Cereal crops } \\
\text { Rangelands }\end{array}$ & Pseudomonas & $A, \mathrm{~B}$ & Pers. comm. \\
\hline $\begin{array}{l}\text { C. Dorworth, D. Macey, } \\
\text { R. Winder } \\
\text { Can. Forest Service } \\
\text { Victoria, B.C. }\end{array}$ & CLMCD & Forest nursery & Pseudomonas & $A$ & Pers. comm. \\
\hline $\begin{array}{l}\text { M. Dumas } \\
\text { Can. Forest Service } \\
\text { Sault Ste. Marie, } \\
\text { Ontario }\end{array}$ & Rubus spp. & Forest & Unidentified & $A$ & Pers. comm. \\
\hline $\begin{array}{l}\text { L. Elliott } \\
\text { USDA-ARS } \\
\text { Corvallis, OR }\end{array}$ & POANN & $\begin{array}{l}\text { Seed crops } \\
\text { Turtgrass }\end{array}$ & Pseudonionas & $A, \mathrm{~B}, \mathrm{C}$ & 14 \\
\hline $\begin{array}{l}\text { J. Frey } \\
\text { Mankato State Univ. } \\
\text { Mankato, MN }\end{array}$ & XANST & Row crops & Pseudomonas & A, B & Pers. comm. \\
\hline $\begin{array}{l}\text { P. Harris, P. Stahlman } \\
\text { Kansas State Univ. } \\
\text { Hays, KS }\end{array}$ & $\begin{array}{l}\text { BROTE, } \\
\text { BROJA } \\
\text { BROSE, } \\
\text { AEGCY }\end{array}$ & Cereal crops & $\begin{array}{l}\text { Enterobacter } \\
\text { Pseudomonas } \\
\text { Xanthomonas }\end{array}$ & A, B, C, D & $20,21,23,24$ \\
\hline $\begin{array}{l}\text { A. Kennedy } \\
\text { USDA-ARS } \\
\text { Pullman, WA }\end{array}$ & $\begin{array}{l}\text { BROTE, } \\
\text { BROJA, } \\
\text { AEGCY, } \\
\text { SSYAL, } \\
\text { AMARE }\end{array}$ & Cereal crops & P. fluorescens & A, B, C, D & $26,29,31$ \\
\hline $\begin{array}{l}\text { R. Kremer } \\
\text { USDA-ARS } \\
\text { Columbia, MO }\end{array}$ & $\begin{array}{l}\text { ABUTH, } \\
\text { AMARE } \\
\text { Ipomoae spp. } \\
\text { Setaria spp } \\
\text { EPHES }\end{array}$ & Row crops & $\begin{array}{l}\text { Pseudonionas } \\
\text { Enterobacter } \\
\text { Erwinia } \\
\quad \text { herbicola } \\
\text { Flavobacterium }\end{array}$ & $\mathrm{A}, \mathrm{B}, \mathrm{C}$ & $33,34,48$ \\
\hline $\begin{array}{l}\text { K. Mortensen, } \\
\text { S. Boyetchko } \\
\text { Agric. Canada } \\
\text { Regina, Saskatchewan }\end{array}$ & $\begin{array}{l}\text { BROTE } \\
\text { SETVI }\end{array}$ & $\begin{array}{l}\text { Cereal crops } \\
\text { Pastures }\end{array}$ & Pseudonionas & A, B & $\begin{array}{l}\text { 6; } \\
\text { Pers. comm. }\end{array}$ \\
\hline $\begin{array}{l}\text { H. D. Skipper } \\
\text { Clemson Univ. } \\
\text { Clemson, SC } \\
\end{array}$ & BROTE & Cereal crops & Pseudomonas & A & $\begin{array}{l}45 ; \\
\text { Pers. comm. }\end{array}$ \\
\hline \multicolumn{6}{|c|}{ 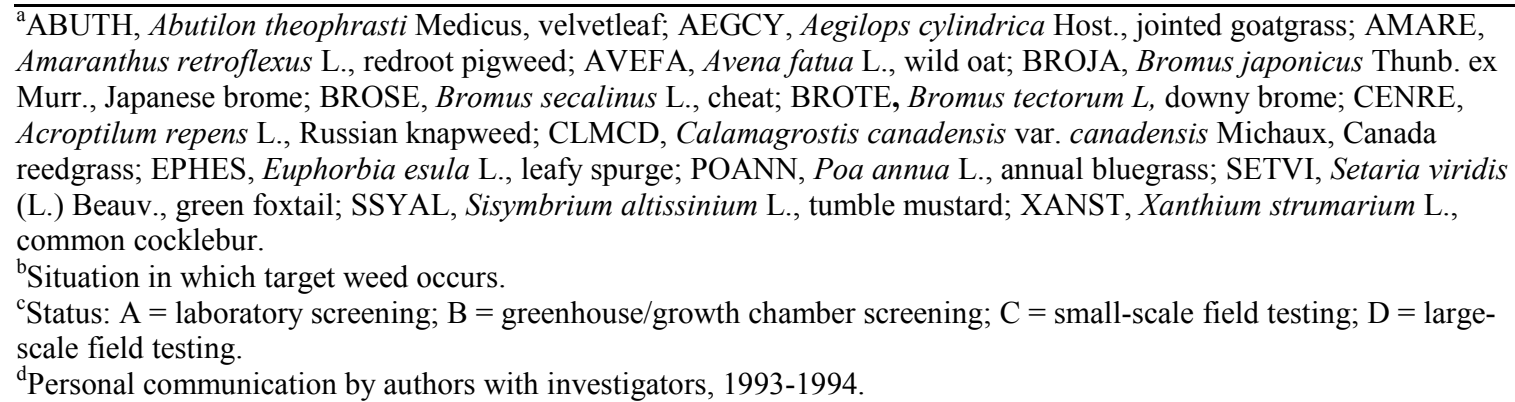 } \\
\hline
\end{tabular}


interactions is needed to develop strategies where DRB selected for activity toward a weed can be paired with a specific chemical that increases susceptibility of the weed to the DRB. Successful development of this integrated strategy will not only increase efficacy of DRB agents but also reduce amounts of herbicides required for weed control and decrease potential environmental contamination.

Combinations of different DRB strains or integration with other types of biological control agents (i.e., fungi, insects) may enhance efficacy of control over that exhibited by either agent alone. A combination of equivalent amounts of inocula of strains P. fluorescens LS102 and Flavobacterium balustinum LS105 applied to soil in the greenhouse resulted in a synergistic increase in inhibition of leafy spurge (Euphorbia esula L. \# EPHES) seedling growth (47). Other work with Agrobacterium spp. reported that crown galls incited on leafy spurge and Russian knapweed [Acroptilum repens L. (DC.) \# CENRE] were often infected with other soilborne bacteria and fungi $(7,8)$. Research is underway to determine if potential biological control of leafy spurge and Russian knapweed by the primary agent, Agrobacterium tumefaciens, might be further enhanced by applying secondary pathogens using the crown gall as the entry point. Other bacteria coinoculated with mycoherbicide agents enhanced diseases caused by the fungal pathogens on velvetleaf (17) and hemp sesbania [Sesbania exaltata (Raf.) Rybd. ex A.W. Hill \# SEBEX] (41). Enhancement of detrimental activity on growth of weeds attacked by insects in association with fungi has been described (25). The most practical application of DRB and insect combinations would be in situations where the insect agent feeds on roots or crowns of target weeds. Indeed, it has been suggested that leafy spurge control resulting from feeding by root-boring larvae of flea beetles (Aphthona spp.) may be enhanced due to secondary invasion by plant pathogens naturally present in soils (38). Exploitation of flea beetle larvae as vectors of DRB selective for suppression of leafy spurge could contribute an additional strategy for control of this noxious range weed and serve as a model for integration of root insect DRB combinations on other weeds.

Cultural practices used for non-chemical weed control offer convenient application methods for integrating DRB biological control of weeds in cropping systems. Tillage can influence the frequency of inhibitory bacteria occurring in soil and their growthsuppressive activity, Downy brome and jointed goatgrass were suppressed by rhizobacteria under either conventional or minimum tillage suggesting that application of selected DRB during tillage may be effective in integrated weed management (31). Vegetative residues at or near the soil surface could serve as substrates for production of weedsuppressive agents by DRB applied directly to the residues. As previously demonstrated, numbers of wheat-inhibitory DRB increased dramatically when applied on crop residues, which promoted production of toxins inhibitory to wheat (49). An approach is envisioned in which DRB are applied on surface residues to produce phytotoxins that suppress weed growth prior to planting the crop, similar to a preemerge herbicide tactic. The feasibility of this approach for pest control was demonstrated by applying biocontrol agents to wheat straw in the field, which reduced populations of the tan spot pathogen [Pyrenophora triticirepentis (Died.) Drechs.] of winter wheat (37).

Manipulation of allelochemicals released from plant residues to stimulate phytotoxic activity of endemic microorganisms is being investigated as a means of controlling Canada reedgrass (Calamagrostis canadensis var. canadensis Michaux \# CLMCD), which is 
detrimental to establishment of tree seedlings in reforestation projects ${ }^{5}$. This unique approach of combining deleterious microorganisms and allelopathy has implications in devising similar strategies for weed management with DRB in minimum tillage systems, in which accumulated residues are readily available sources of allelochemicals. Crop rotation is a practice that may also be manipulated to encourage development of specific inhibitory bacteria on weed roots. Previous work reporting a rotation effect in corn (Zea mays L.) was due partly to certain rhizobacteria specifically associated with corn roots illustrates the potential for using DRB to achieve suppression of weeds in crop rotation systems (54).

\section{Research needs}

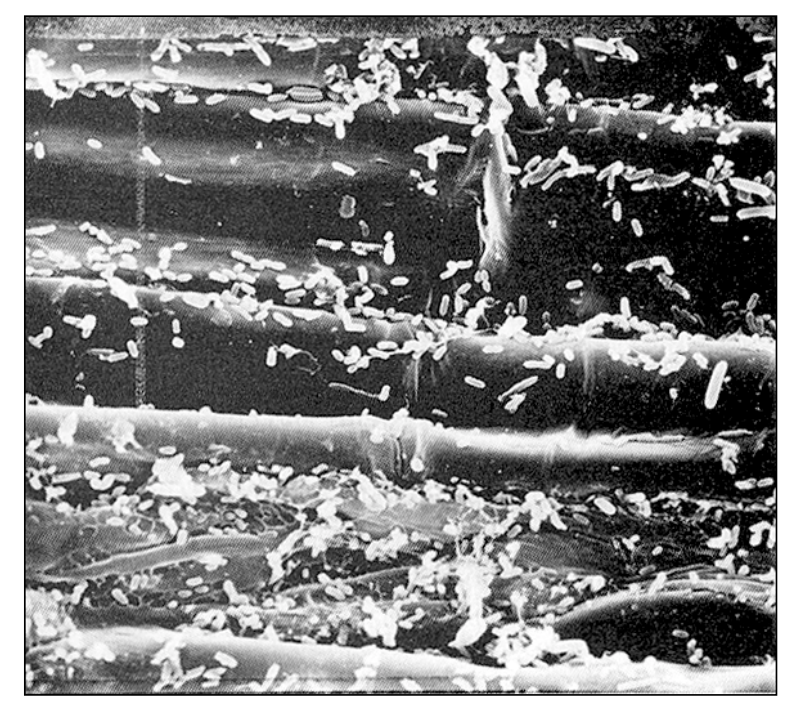

Figure 3. Root surface of a two-week old velvetleaf root inoculated with $P$. fluorescens strain 239 showing bacterial cells aligned in intercellular spaces of root epidermal cells. Magnification x 4,800. Scanning electron micrograph from Begonia (4).

The need to enhance efficacy of weed control will determine research approaches taken to improve biological control strategies based on DRB. DRB should possess rootcolonizing attributes of survival and competitiveness in soil and rhizosphere environments, aggressive rhizosphere colonization, ability to express inhibitory traits on the rhizoplane, and adaptability to unique delivery systems (5). Observations with scanning electron microscopy have revealed a relationship between rhizoplane colonization by DRB (Figure 3) and plant growth suppression (4). However, actual mechanisms of root colonization need further evaluation in soil-rhizosphere environments (32). For example, the seasonal colonization patterns of $P$. fluorescens D7 in soil and on downy brome roots illustrated that colonization was a major factor in establishing and sustaining the observed growth suppression (29) throughout the winter wheat growing season (Figure 4). Colonization of soil and roots declined late in the season and did not recover, indicating that annual application of DRB to the field is necessary. Thus, approaches for maintaining high and persistent numbers of DRB in soil must be developed.

Systematic protocols for selection of effective rhizobacteria should, therefore, be based on critical ecological traits that are required for expression of activity toward the target pest $(35,45)$. Kloepper $(32)$, noting the considerable effort involved in ongoing programs for screening numerous rhizobacterial isolates, suggests that the inherent diversity of bacteria collected from rhizosphere environments increases the chance to diversify the mechanisms of biological control, thereby increasing chances of developing agents that will give predictable control under practical agricultural situations. Currently, proto-

\footnotetext{
${ }^{5}$ R. Winder. 1993. Canadian Forest Service, Victoria, B.C. Canada. Unpublished manuscript.
} 
cols for selecting DRB with highest potential for biological control of weeds are being developed $(21,29,48)$ and will serve as models for future DRB selection programs. Bioassays are not limited to seedlings as indicators of bioactivity. Inhibitory activity of leafy spurge DRB in plant tissue cultures was directly correlated to seedling bioassays and efficiency of screening on leafy spurge was increased due to low viability and limited sources of seeds (48).

Rationale for selection of specific weeds to be targeted for biological control using DRB has not been described adequately. Watson and Wymore (56) suggest that weeds not adequately controlled by herbicides are ideal candidates for biological control. However, if current widely used herbicides become highly restricted or banned in certain areas in the future, agents for several major weeds controlled by these herbicides will be needed. Selection of weed species also should consider weeds with high potential for development of herbicide tolerance/resistance and weeds problematic in shifts caused by changes in cultural practices. A compilation of weeds based on these traits and their relative economic importance could be ranked and assigned indices based on their occurrence and importance in crop production regions (42). The top-scoring weeds in each cropping system then would be prime targets for biological control.

The deleterious activity of most rhizobacteria is due to the production of phytotoxins $(48,53)$. Rhizobacteria for biological control of weeds likely produce phytotoxins at root surfaces where they are readily absorbed by the plant (Figure 3 ). There is currently some question whether phytotoxins produced in culture and applied alone as a bioherbicide are as effective in controlling weeds compared to application of the intact organism. Durbin (13) points out that some bacterial pathogens are unable to produce phytotoxins in culture but only produce them in planta. Therefore, a complete understanding of the conditions required for optimum and effective phytotoxin production is necessary. Successful establishment of rhizobacteria that produce high levels of phytotoxin in the rhizosphere would be more economical than chemical synthesis and application of the compound (2). Work with rhizobacteria on leafy spurge illustrates that some strains are more effective in causing plant injury when intact, whole cells are used as inoculum compared to cell-free culture filtrate containing phytotoxic metabolites $(47,48)$. Investigations are needed to develop methods to maximize phytotoxin production both in vitro and in planta. Determination of phytotoxin structure would indicate the type of precursor compounds useful for enhancing phytotoxin production in culture media and/or inoculum carriers added to

Page 10 of 14 
soil. We recently characterized rhizobacteria that produced high amounts of indole compounds, which are reportedly detrimental to plant growth (44). Growth inhibitory activity of one DRB isolate toward several weed species was significantly enhanced when combined with low levels of tryptophan, a precursor for indole compounds (39). High performance liquid chromatography analyses of extracts of this culture detected high concentrations of several indole compounds, including indole acetic acid and indole acetaldehyde.

Implementation of biological control with DRB is through primarily an inundative strategy. Formulation of a delivery system that promotes survival and colonization of weed seeds and roots by DRB in the field is critical in attaining a high level of efficacy. Mycoherbicide formulations that provide optimum conditions for fungal activity on weeds are bases for developing similar inocula containing DRB (12). Use of alginateencapsulated Pseudomonas fluorescens to control soilborn fungal pathogens resulted in high survival and efficient colonization of wheat roots in soil (55). Clay encapsulation of $P$. fluorescens D7 enhanced survival and increased biocontrol efficacy toward downy brome by 20 to $40 \%{ }^{6}$. These preliminary results are encouraging and illustrate that preparation of inocula based on alginate and clay formulations will likely maintain efficacy of DRB under field conditions.

Efficacy of DRB in field studies has been attributed partly to reduced competitiveness of weeds due to growth suppression by DRB $(24,29)$. Reduced competition was also demonstrated with rust (Puccinia lagenophorae Cooke) infected common groundsel (Senecio vulgaris L. \# SENVU), which resulted in two- to three-fold increases in lettuce (Lactuca sativa L.) yields compared to yield in plots containing healthy groundsel (36).

Increasing crop interference in the field by manipulating row spacing, seeding rates, and other cultural practices to reduce weed growth has been proposed as a viable component of integrated weed management (28). Highly competitive varieties selected through crop breeding and management could be used in conjunction with weed-suppressive DRB and further enhance effectiveness and acceptance of integrated weed management systems emphasizing nonchemical control.

\section{Summary}

The rhizobacterial approach to biological control of weeds is in the early developmental stages and will expand as current and future projects progress from empirical screening toward commercial evaluation of promising agents. Future direction of DRB as biological control agents for weeds will depend on intensive, fundamental research in the areas of ecology and biological activity of bacteria-plant relationships to better understand and exploit efficacy-based mechanisms and in development of suitable formulations for delivery to the field. As more efficacious DRB-based strategies for consistent suppression of weed growth are developed, the prospects for acceptance in production

\footnotetext{
${ }^{6}$ A. C. Kennedy and A. G. Ogg, Jr., USDA-ARS, Pullman, WA 99164-6421; H. D. Skipper, Dep. Agron. Soils, Clemson Univ., Clemson, SC 29634-0359; and R. S. Smith, LyphaTech, Inc., Milwaukee, WI 53209. 1993. Unpublished data.
}

Page 11 of 14 
systems and commercial development should increase considerably. The DRB approach offers an additional biological control strategy that can supplement current mycoherbicides and also offer augmentative control options as herbicide use becomes more restricted.

\section{Literature cited}

1. Aldrich, R. J. 1984. Weed-Crop Ecology: Principles in Weed Management. New Breton Publ., North Scituate, Mass. 465 p.

2. Arshad, M. and Frankenberger W. T., Jr. 1991. Microbial production of plant hormones. Plant Soil 133: $1-8$.

3. Bakker, A. W. and B. Schippers. 1987. Microbial cyanide production in the rhizosphere in relation to potato yield reduction and Pseudomonas spp.-mediated plant growth reduction. Soil Biol. Biochem. 19:452-458.

4. Begonia, M.F.T. 1989. Characterization of attraction of rhizobacteria to weed seeds and seedlings. Ph.D. Diss. Univ. of Missouri, Columbia, MO. 165 p.

5. Bolton, J. H., J. K. Fredrickson, and L. F. Elliott. 1992. Microbial ecology of the rhizosphere. p. 27-63 in F. B. Metting, Jr., ed. Soil Microbial Ecology. Marcel Dekker, New York.

6. Boyetchko, S. M. and K. Mortensen. 1993. Use of rhizobacteria as biological control agents of downy brome. p. 443-448 in Proc. Soils Crops Workshop. Saskatoon, Saskatchewan, Canada.

7. Caesar, A. J. 1994. Pathogenicity of Agrobacterium species from the noxious rangeland weeds Euphorbia esula and Centaurea repens. Plant Dis. 78:796-800.

8. Caesar, A. J., P. C. Quimby, N. E. Rees, and N. R. Spencer. 1992. Diseases of leafy spurge in the northern Great Plains. p. 37-40 in Great Plains Agric. Counc. Publ. No. 44.

9. Charudattan, R. 1989. Assessment of efficacy of mycoherbicide candidates. p. 455-464 in E. S. Delfosse, ed. Proc. VII Int. Symp. Biol. Control Weeds. 1st. Sper. Patol. Veg. (MAF), Rome, Italy.

10. Charudattan, R. 1991. The mycoherbicide approach with plant pathogens. p. 24-57 in D. O. TeBeest, ed. Microbial Control of Weeds. Chapman and Hall, New York.

11. Cherrington, C. A. and L. F. Elliott. 1987. Incidence of inhibitory pseudomonads in the Pacific Northwest. Plant Soil 101:159-165.

12. Daigle, D. J. and W. J. Connick, Jr. 1990. Formulation and application technology for microbial weed control. p. 288-304 in R. E. Hoagland, ed. Microbes and Microbial Products as Herbicides. Am. Chem. Soc., Washington, DC.

13. Durbin, R. D. 1983. The biochemistry of fungal and bacterial toxins and their modes of action. p. 137-162 in J. A. Callow, ed. Biochemical Plant Pathology. John Wiley \& Sons, New York.

14. Elliott, L. F., W. R. Horwath, and G. W. Mueller-Warrant. 1994. Biocontrol of annual bluegrass with deleterious rhizobacteria. Agron. Abstr. 58:280.

15. Elliott, L. F. and A. C. Kennedy. 1991. Method for screening bacteria and application thereof for field control of the weed downy brome. U.S. Patent no. 5,030,562.

16. Elliott, L. F. and J. M. Lynch. 1985. Pseudomonads as a factor in the growth of winter wheat (Triticum aestivum L.). Soil Biol. Biochem. 16:69-71.

17. Fernando, W. G. D., A. K. Watson, and T. C. Paulitz. 1994. Phylloplane Pseudomonas spp. enhance disease caused by Colletotrichum coccodes on velvetleaf. Biol. Control 4:125-131. 
18. Gianessi, L. P. and C. Puffer. 1991. Herbicide use in the United States: National summary report. Resources for the Future, Washington, D.C. 128 p.

19. Greaves, M. P. and J. A. Sargent. 1986. Herbicide-induced microbial invasion of plant roots. Weed Sci. 34 (Suppl. 1):50-53.

20. Harris, P. A. and P. W. Stahlman. 1991. Biocontrol of Bromus and Aegilops spp. in winter wheat using deleterious rhizobacteria. Agron. Abstr. 55:266.

21. Harris, P. A. and P. W. Stahlman. 1992. Biological weed control in wheat using deleterious rhizobacteria. Weed Sci. Soc. Am. Abstr. 32:50.

22. Harris, P. A. and P. W. Stahlman. 1992. Soil bacteria combined with various herbicides suppress winter annual grass weeds. Agron. Abstr. 56:258.

23. Harris, P. A. and P. W. Stahlman. 1993. Selective biocontrol of winter annual grass weeds in winter wheat. North Cent. Weed Sci. Soc. Proc. 48:6.

24. Harris, P. A. and P. W. Stahlman. 1993. Soil bacteria selectively inhibit winter annual grass weeds in winter wheat. Agron. Abstr. 57:250.

25. Hasan, S. and P. G. Ayers. 1990. The control of weeds through fungi: Principles and prospects. New Phytol. 115:201-222.

26. Johnson, B. N., J. A. Doty, T. L. Stubbs, and A. C. Kennedy. 1993. Efficacy and specificity of rhizobacteria for the control of weeds. Agron. Abstr. 57:252.

27. Johnson, B. N., A. C. Kennedy, and A. G. Ogg, Jr. 1993. Suppression of downy brome growth by a rhizobacterium in controlled environments. Soil Sci. Soc. Am. J. 57:73-77.

28. Jordan, N. 1993. Prospects for weed control through crop interference. Ecol. Appl. 3:84-91.

29. Kennedy, A. C., L. F. Elliott, F. L. Young, and C. L. Douglas. 1991. Rhizobacteria suppressive to the weed downy brome. Soil Sci. Soc. Am. J. 55:722-727.

30. Kennedy, A. C., A. G. Ogg, Jr., and F. L. Young. 1992. Biocontrol of jointed goatgrass. Patent no. $5,163,991$.

31. Kennedy, A. C., T. L. Stubbs, and F. L. Young. 1989. Rhizobacterial colonization of winter wheat and grass weeds. Agron. Abstr. 53:220.

32. Kloepper, J. W. 1992. Plant growth-promoting rhizobacteria as biological control agents. p. 255-274 in F. B. Metting, Jr., ed. Soil Microbial Ecology. Marcel Dekker, Inc., New York.

33. Kremer, R. J. 1993. Management of weed seed banks with microorganisms. Ecol. Appl. 3:42-52.

34. Kremer, R. J., M.F.T. Begonia, L. Stanley, and E. T. Lanham. 1990. Characterization of rhizobacteria associated with weed seedlings. Appl. Environ. Microbiol. 56:1649-1655.

35. Nijhuis, E. H., M. J. Maat, I.W.E. Zeegers, C. Waalwijk, and J. A. Van Veen. 1993. Selection of bacteria suitable for introduction into the rhizosphere of grass. Soil Biol. Biochem. 25:885-895.

36. Paul, N. D. and P. G. Ayers. 1987. Effects of rust infection of Senecio vulgaris on competition with lettuce. Weed Res. 27:431-441.

37. Pfender, W. F., W. Zhang, and A. Nus. 1993. Biological control to reduce inoculum of the tan spot pathogen Pyrenophora tritici-repentis in surface-borne residues of wheat fields. Phytopathology $83: 371-375$.

38. Rees, N. E. and N. R. Spencer. 1991. Biological control of leafy spurge. p. 182-192 in L. F. James, ed. Noxious Range Weeds. Westview Press, Boulder, CO.

39. Sarwar, M. and R. J. Kremer. 1995. Enhanced suppression of plant growth through production of L-tryptophan-derived compounds by deleterious rhizobacteria. Plant Soil 172:261-269. 
40. Schippers, B., A. W. Bakker, and P. A. Bakker. 1987. Interaction of deleterious and beneficial rhizosphere microorganisms and the effect of cropping practices. Annu. Rev. Phytopathol. 25:339-358.

41. Schisler, D. A., K. M. Howard, and R. J. Bothast. 1991. Enhancement of disease caused by Colletotrichum truncatum in Sesbania exaltata by coinoculating with epiphytic bacteria. Biol. Control 1:261-268.

42. Schroeder, D., H. Mueller-Schaerer, and C.S.A. Stinson. 1993. A European weed survey in 10 major crop systems to identify targets for biological control. Weed Res. 33:449-458.

43. Schroth, M. N. and J. G. Hancock. 1982. Disease-suppressive soil and root-colonizing bacteria. Science 216:1376-1381.

44. Schroth, M. N., J. E. Loper, and D. C. Hildebrand. 1984. Bacteria as biocontrol agents of plant disease. p. 362-369 in M. J. Klug and C. A. Reddy, eds. Current Perspectives in Microbial Ecology. Am. Soc. Microbiol., Washington, DC.

45. Skipper, H. D., A. G. Ogg, Jr., and A. C. Kennedy. 1996. Root biology of grasses and ecology of Rhizobacteria for biological control. Weed Technol. 10:610-620.

46. Smith, R. J., Jr. 1991. Integration of biological control agents with chemical pesticides. p. 189-208 in D. O. TeBeest, ed. Microbial Control of Weeds. Chapman and Hall, New York.

47. Souissi, T. 1994. Rhizobacteria in weed management: Biological control of leafy spurge (Euphorbia esula). Ph.D. Diss. Univ. of Missouri, Columbia, MO. 130 p.

48. Souissi, T. and R. J. Kremer. 1994. Leafy spurge (Euphorbia esula) cell cultures for screening deleterious rhizobacteria. Weed Sci. 42:310-315.

49. Stroo, H. F., L. F. Elliott, and R. I. Papendick. 1988. Growth, survival and toxin production of rootinhibitory pseudomonads on crop residues. Soil Biol. Biochem. 20:201-207.

50. Stubbs, T. L. and A. C. Kennedy. 1993. Effect of bacterial and chemical stresses in biological weed control systems. Agron. Abstr. 57:261.

51. Suslow, T. V. and M. N. Schroth. 1982. Role of deleterious rhizobacteria as minor pathogens in reducing crop growth. Phytopathology 72:111-115.

52. TeBeest, D. O., X. B. Chang, and C. R. Cisar. 1992. The status of biological control of weeds with fungal pathogens. Annu. Rev. Phytopathol. 30:637-657.

53. Tranel, P. J., D. R. Gealy, and A. C. Kennedy. 1993. Inhibition of downy brome (Bromus tectorum) root growth by a phytotoxin from Pseudomonas fluorescens strain D7. Weed Technol. 7:134-139.

54. Turco, R. F, M. Bischoff, D. P. Breakwell, and D. R. Griffith. 1990. Contribution of soil-borne bacteria to the rotation effect in corn. Plant Soil 122:115-120.

55. van Elsas, J. D., J. T. Trevors, D. Jain, A. C. Wolters, C. E. Heijnen, and L. S. van Overbeek. 1992. Survival of, and root colonization by, alginate-encapsulated Pseudomonas fluorescens cells following introduction into soil. Biol. Fertil. Soils. 14:14-22.

56. Watson, A. K. and L. A. Wymore. 1990. Identifying limiting factors in the biocontrol of weeds. p. 305-316 in P. H. Dunn, ed. New Directions in Biological Control: Alternatives for Suppressing Agricultural Pests and Diseases. Alan R. Liss, Inc., New York. 